\title{
Metal content in fruit-bodies and mycorrhizas of Pisolithus arrhizus from zinc wastes in Poland
}

\author{
KATARZYNA TURNAU ${ }^{1}$, EWA GUCWA ${ }^{2}$, PIOTR MLECZKO $^{1}$, and BARBARA GODZIK ${ }^{3}$ \\ Institute of Botany of Jagiellonian University \\ Lubicz 46, PL-31-512 Kraków, Poland \\ ${ }^{2}$ Institute of Botany of Silesian University \\ Jagielloniska 28, PL-40-032 Katowice, Poland \\ ${ }^{3}$ Institute of Botany of the Polish Academy of Sciences \\ Lubicz 46, PL-31-512 Krakow, Poland
}

Turna u K., G uew a E., M le ezko P. G odzik. B.: Metal content in fruit-bodies and mycorrhizas of Pisolithus arrhizus from zinc wastes in Poland. Acta Mycol. 33 (1): $59-67,1998$.

Pisolithus arrhizus has been selected for investigation as one of the ectomycorrhizal species most resistant to stress factors. Metal content in fruit-bodies and mycorrhizas was estimated to evaluate their role as bioindicators and to check whether mycorrhizas have any special properties for heavy metal accumulation. Fruit-bodies and mycorrhizas were collected from zinc wastes in Katowice-Welnowiec and analyzed using conventional atomic absorption spectroscopy and energy dispersive spectroscopy accompanying scanning electron microscopy. Dillerences in tendencies to accumulate metals within sporophores and mycorrhizas were found. The fruit-bodies accumulated $\mathrm{Al}$ (up to $640 \mu \mathrm{g} \mathrm{g}^{-1}$ ), while high concentrations of $\mathrm{Al}, \mathrm{Zn}, \mathrm{Fe}, \mathrm{Ca}$ and $\mathrm{Si}$ were noted in the outer mantle of the mycorrhizas, in the matcrial secreted and in the mycelium wall. The content of elements varied depending on the age of mycorrhizas. The ability of cxtramatrical mycelium and hyphae forming mycorrhizal mantle to immobilize potentially toxic elements might indicate biofiltering properties though the next step should include investigations on ability of the fungus to prevent element uptake by the plant.

Key words: Pisolithus arrhizus, heavy metals, Al bioaccumulation, X-ray analysis (EDS), AAS. SFM.

\section{INTRODUCTION}

Pisolithus arrhizus (Pers.) Rausch. (= Pisolithus tinctorius (Pers.) Cocker et Couch) is one of the most intensively studied ectomycorrhizal fungi. It is considered to be a very effective species in the recultivation of heavily polluted or disturbed areas ( $\mathrm{L}$ a n d is et al. 1990). In natural communities it is 
a relatively rare species occurring on poor, sandy soils and forming mycorrhizas with a broad range of host species. It is noted quite frequently on mining wastes of brown and black coal, slate, kaolin and black wastes from anthracite mining ( $\mathrm{S} \mathrm{ch} \mathrm{ram} \mathrm{m}$ 1966; L is i ew s k and Sied la cze k 1982; Derbsch and $\mathrm{Schmitt} \mathrm{1987;} \mathrm{Kreis} \mathrm{e} \mathrm{1} \mathrm{1987).} \mathrm{The} \mathrm{fruit-bodies}$ are known to accumulate high levels of $\mathrm{Al}$ and $\mathrm{Cr}(\mathrm{M} \mathrm{ed} \mathrm{ve}$ and $\mathrm{S}$ a y r e 1994; C ochrane 1978). The species improves the growth of Pims strobus seedlings in substratum supplemented with $\mathrm{Al} \mathrm{(S} \mathrm{ch} \mathrm{i} \mathrm{e} \mathrm{r} \mathrm{and}$ M c Q u a t t i e 1995) also diminishing the foliar symptoms of Al toxicity. Although the authors suggested that the amelioration of $\mathrm{Al}$ toxicity by mycorrhizal colonization resulted from enhanced uptake of nutrients, especially $\mathrm{P}$, rather than the reduced uptake of $\mathrm{Al}$, the data presented show a significant decrease in the $\mathrm{Al}$ content of the needles of mycorrhizal seedlings. According to T a m (1995) the mycelium of Pisolithus arrhizus cultivated on agar medium was able to withstand high concentrations of $\mathrm{Al}, \mathrm{Fe}, \mathrm{Cu}$ or $\mathrm{Zn}$ and to a much lesser extent $\mathrm{Ni}, \mathrm{Cd}, \mathrm{Cr}$ and $\mathrm{Hg}$. The energy dispersion $\mathrm{X}$-ray spectroscopy showed that the slime produced on the surface of the mycelium and cell wall were responsible for the complexation of potentially toxic clements. A pigmented cell wall layer of $P$. arrhizus mycelium cultivated on media supplemented with cadmium dust was observed using electron energy loss spectroscopy, to contain $\mathrm{Al}$ and $\mathrm{Cd}$ ( $\mathrm{T} \mathrm{u} \mathrm{r}$ n a u et al. 1994). At the same time the presence of cysteine-rich proteins in the same cell wall layer was demonstrated. G r u h n and M ille r (1991) indicated that tyrosinase, the enzyme active in melanin formation, might also be stimulated by the presence of heavy metals. Further TEM investigations by $\mathrm{T} u \mathrm{r} \mathrm{n}$ a u et al. (1994) showed intracellular localization of the metals in P. arrhizus cultivated on agar containing heavy metals. Such elements as $\mathrm{Cd}, \mathrm{Ti}, \mathrm{Ni}, \mathrm{Cu}$, $\mathrm{Al}, \mathrm{Fe}$ as well as $\mathrm{P}, \mathrm{S}$ and $\mathrm{N}$ were found in phosphate-rich, vacuolar material giving a positive reaction to the Gomori-Swift test for cysteine-rich material. This suggested the possibility of metal-binding protein deposition within vacuoles as a resistance mechanism. The existence of proteins with thiolate clusters in $P$. arthizus cultivated in heavy metal supplemented media were indicated cytochemically by $\mathrm{M}$ orse $1 \mathrm{t}$ et al. (1986). Metallothionein-like proteins have been widely implicated in the detoxification and storage of cadmium, zine and copper ions ( $\mathrm{K}$ a g i and $\mathrm{K}$ o j i m a 1987). Among ectomycorrhizal fungi, only in case of Laccaria laccata and Paxillus involutus copper binding proteins of this kind have been isolated and characterized (Howe et al. 1997). Strains of the same species differ in their ability to produce the substances.

The successful growth of the mycelium could also be attributed to the resistance of acid phosphatase to heavy metals and to an efficient system of dolipori cutting off parts of the mycelitum which have taken up lethal levels of 
metals (T urna and Dex heimer 1995). Most of the above mentioned papers are concerned with mycelium grown in agar cultures.

The present paper is part of a study on metal tolerant ectomycorrhizal fungi, their selection, characterization and utilization for restoration of polluted forests. The metal content in fruit-bodies and mycorrhizas of $P$. arrhizus collected from zinc wastes in Katowice, were determined to evaluate their importance for bioindication of potentially toxic elements and to check whether mycorrhizal mantle has special properties for heavy metal accumulation.

\section{MATERIAL AND METHODS}

Fruit-bodies of Pisolithus arrhizus were found in summer 1996 in close vicinity to Betula pendula and Populus tremula on 20-year-old zinc wastes in Katowice-Wehowiec (N-W part of the wastes). The $\mathrm{pH}$ value of the spoil mound ranged from 6.4 to 8.2 but in the place where $P$. arrhizus occurred the value was 3.8 to 3.9 . The wastes were characterized by low levels of organic matter, nitrogen, phosphorus and high levels of heavy metals concentrated mainly in the surface layer ( $\mathrm{T} \circ \mathrm{k}$ a r s k a-G u z i k et al. 1991). Composite soil samples $(0-5 \mathrm{~cm})$ for chemical analysis were collected from the place where $P$. arrhizus was localized and from several other areas of the wastes of similar age. The analysis of the total content of elements (extracted in $1 \mathrm{~N} \mathrm{HCl}$ ) in soil. which were estimated with atomic absorption spectrophotometer (Varian 20BQ), showed that the surface layer of the wastes was an extremely heterogenous material regarding the element content (Tab. 1). The part of the wastes where $P$, arrhizus was found differed significantly from the rest of the wastes with respect to the element content and $\mathrm{pH}$ value. Only the levels of $\mathrm{Al}$ and $\mathrm{Cu}$ were similar as in the other parts of the wastes. The analysis of metals extracted in $\mathrm{Ca}\left(\mathrm{NO}_{3}\right)_{2}$ revealed much lower availability of such elements as $\mathrm{Pb}$ and $\mathrm{Cd}$ while a reverse case was observed for $\mathrm{Cu}$ and $\mathrm{Zn}$ (Tab. 1).

The content of elements in fruit-bodies was determined by AAS after wet digestion with a $4: 1$ mixture of nitric and perchloric acids.

Roots for ectomycorrhiza selection were collected from the locations where fruit-bodies were present. Mycorrhizas were selected under a stereomicroscope and identified according to A g e re r $(1987-1995)$ and W e is s (1991, 1992). They were washed, air dried, mounted on carbon stubs and covered with carbon. The outer layer of the mycorrhizal mantles was subsequently analyzed with energy dispersive spectrometry (EDS) with a lithum-silicon detector (NORAN) connected to scanning microscope Jeol JSM 5410. The estimated depth of the electron beam penetration was $3-5 \mu \mathrm{m}$ (Monte Carlo Simulation by David C. Joy, version Feb. 1995). Computer analysis was carried out using the Voyager 3.6 program. 
$\mathrm{Tab} / \mathrm{e} 1$

Total element content (extracted in $1 \mathrm{~N} \mathrm{HCl}$ ) and $\mathrm{Ca}\left(\mathrm{NO}_{3}\right)_{2}$ extractable metals in the 25-year-old zine waste substratum outside and in the place where $P$. arrhizus occurred (mg kg $\mathrm{kg}^{-1} \mathrm{dry}$ weight)

\begin{tabular}{|c|c|c|c|c|}
\hline & $\begin{array}{c}\text { Zinc waste substratum } \\
\text { extraction in } \\
\mathrm{HCl}\end{array}$ & $\begin{array}{c}\text { Zinc waste substratum } \\
\text { extraction in } \\
\mathrm{Ca}\left(\mathrm{NO}_{3}\right)_{2}\end{array}$ & $\begin{array}{l}\text { P. arrhizus stand } \\
\text { extraction in } \\
\text { HCl }\end{array}$ & $\begin{array}{l}\text { P. arrhizus stand } \\
\text { extraction in } \\
\mathrm{Ca}\left(\mathrm{NO}_{3}\right)_{2}\end{array}$ \\
\hline $\mathrm{Pb}$ & 17630 & 1.5 & 380 & 1.8 \\
\hline $\mathrm{Zn}$ & 18512 & 42.5 & 1.794 & 94.7 \\
\hline $\mathrm{Cd}$ & 528 & 2.5 & 43 & 0.06 \\
\hline $\mathrm{Cu}$ & 380 & 0.3 & 882 & 4.8 \\
\hline $\mathrm{Fe}$ & 17713 & nd. & 850 & n.d \\
\hline $\mathrm{Mn}$ & 36333 & nd. & 41 & n.d \\
\hline $\mathrm{Ca}$ & 71583 & nd. & 3312 & n.d. \\
\hline Al & 3599 & n.d. & 2796 & n.d. \\
\hline $\mathrm{Cr}$ & n.d. & n.d. & 15.8 & n.d. \\
\hline
\end{tabular}

n.d. - not determined

\section{RESULTS AND DISCUSSION}

\section{Element content in fruit-bodies of $P$. arrhizus}

Nearly 10 times less Ca (up to $400 \mu \mathrm{g} \mathrm{g}^{-1}$ ), $\mathrm{Zn}$ (up to $150 \mu \mathrm{g} \mathrm{g}^{-1}$ ), Fe (up to $\left.90 \mu \mathrm{g} \mathrm{g}^{-1}\right)$ and about 4 times less Al $\left(640 \mu \mathrm{g} \mathrm{g}^{-1}\right)$ were found in fruit-bodies of $P$. arrhizus (Tab. 2) than in the substratum collected from places where the fungus was growing. A similar situation was observed in the case of such elements as $\mathrm{Cu}$, which however did not exceed $10 \mu \mathrm{g} \mathrm{g}^{-1}$, while $\mathrm{Cd}$ and $\mathrm{Pb}$ levels were below $1 \mu \mathrm{g} \mathrm{g}^{-1}$. T y I e r (1980) defined the terms bioconcentration and bioexclusion as the concentration of a metal respectively ten times higher or lower than the mean value estimated for a wide range of fungal species. According to these definitions $P$. arrhizus from zinc wastes in Katowice-Welnowiec had the property of $\mathrm{Al}$ bioconcentration as its level in the fruit-bodies of this species was over 20 times higher than the mean content of $\mathrm{Al}$ in fungal sporophores analyzed by T y l e r (1980). Considering data for 130 species of Basidiomycetes given by $\mathrm{T}$ y $\mathrm{ler}$ (1980), in $P$. arrhizus sporophores levels of $\mathrm{Cu}, \mathrm{Cd}, \mathrm{Ni}, \mathrm{Na}$ and $\mathrm{K}$ are rather low while the values of $\mathrm{Pb}, \mathrm{Cr}, \mathrm{Fe}$, $\mathrm{Zn}$ and $\mathrm{Mg}$ are close to the mean values obtained for other fungi. 
Comparatively high (three times higher than the mean values for basidiomycete fruit-bodies) levels of $\mathrm{Ca}$ were found in $P$. arrhizus sporophores from Poland. The species was also analyzed by $\mathrm{Medve}$ and $\mathrm{S}$ a y r e (1994) from bituminous stripmine spoils whose substratum was characterized by lower $\mathrm{Zn}, \mathrm{Cd}$ and $\mathrm{Cu}$ contents while $\mathrm{Al}$ exceeded the level of $\mathrm{Al}$ in zinc wastes in Katowice - Wełnowiec by more than three times. In this case the Al content in fruit-bodies of $P$. arrhizus was also 3-4 times higher than in the case of sporophores collected from Polish zinc wastes. Al bioconcentrators are rather rare. $\mathrm{T}$ y $1 \mathrm{e} \mathbf{r}$ (1980) found only one case of this phenomenon - Hymenochaete sp. in which a maximum of $427 \mu \mathrm{g} \mathrm{g}^{-1}$ was measured. M e d $v$ e and $\mathrm{S}$ a y $\mathrm{re}$ (1994) also found bioconcentration of $\mathrm{Cr}$ in $P$. arrhizus, which was not indicated in fruit-bodies of fungi growing in Poland. The terms "bioconcentrators" and "bioexcluders" do not take into account any kind of relation to the metal content or their "bioavailability" in the substratum. Despite the high levels of total heavy metal content in the waste material in Poland the contents of $\mathrm{Pb}$ and $\mathrm{Zn}$ extractable in $\mathrm{Ca}\left(\mathrm{NO}_{3}\right)_{2}$ are more similar to the levels found in $P$. arrhizus sporophores (Tabs 1,2). At the same time the content of $\mathrm{Cd}$ was 10 times higher and that of $\mathrm{Cu}$ twice as high as the respective $\mathrm{Cd}$ and $\mathrm{Cu}$ levels extracted in $\mathrm{Ca}\left(\mathrm{NO}_{3}\right)_{2}$ from the waste material.

\section{Metal content in the fungal mantle of $\boldsymbol{P}$. arrhizus mycorrhizas}

The analysis of metal content in P. arrhizus carried out by EDS connected to SEM revealed the accumulation of such elements as $\mathrm{Fe}, \mathrm{Zn}, \mathrm{Al}, \mathrm{Ca}$ and $\mathrm{Si}$ within hyphae of the outer mantle (Tab. 3). The content of elements increased with the age of the mycorrhiza. Considerably high levels of $\mathrm{Ca}, \mathrm{Al}, \mathrm{Ti}$ and $\mathrm{Mg}$ were found in dead mycorrhizas. The accumulative role of the mantle is possible as it was already shown in the case of other mycorrhizas ( $\mathrm{T} \mathrm{u} \mathrm{r} \mathrm{n}$ a u et al. 1996). The mycorrhizas of $P$. arrhizus from zinc wastes in Katowice-Welnowiec observed with SEM showed a very compact structure of the mantle. The hyphae were interconnected by the abundant extracellular material. De n $\mathrm{ny}$ and $\mathrm{R} \mathrm{idge} \mathrm{(1995)} \mathrm{suggested} \mathrm{that} \mathrm{fungal} \mathrm{slime} \mathrm{was}$ 
Ta b l e 3

Element content in mycorrhizas of Pisolithus arrhizus collected from zine wastes in Katowice-Wełnowiec

\begin{tabular}{|l|c|c|}
\hline & Mean value & SD \\
\hline $\mathrm{Zn}$ & 0.23 & 0.15 \\
\hline $\mathrm{Fe}$ & 1.09 & 0.53 \\
\hline $\mathrm{Mg}$ & 0.16 & 0.03 \\
\hline $\mathrm{Al}$ & 2.57 & 1.35 \\
\hline $\mathrm{Ca}$ & 2.19 & 0.99 \\
\hline $\mathrm{Si}$ & 3.10 & 1.77 \\
\hline $\mathrm{P}$ & 0.11 & 0.08 \\
\hline $\mathrm{S}$ & 0.23 & 0.05 \\
\hline $\mathrm{Cl}$ & 0.09 & 0.03 \\
\hline $\mathrm{K}$ & 0.46 & 0.05 \\
\hline $\mathrm{Na}$ & 0.11 & 0.03 \\
\hline $\mathrm{Ti}$ & 0.06 & 0.02 \\
\hline
\end{tabular}

Explanation: data obtained with energy dispersive spectroscopy (EDS); data given in $\%$ total element weight the principal metal binding site, which certainly took part in the detoxification mechanism in the present case. In addition the presence of polysaccharidous material (PATAg test) and cysteine rich proteins (Gomori-Swift reaction) within the cell wall of $P$. arrhizus mycelium was indicated by $\mathrm{Turna}$ u et al. (1994). It was demonstrated that such elements as $\mathrm{Ca}$, $\mathrm{Al}$ and low levels of $\mathrm{Cd}$ were found within the outer wall layer in fixed, dehydrated and embedded in resin mycelium. The results presently obtained confirmed the presence of $\mathrm{Ca}$ and $\mathrm{Al}$ but also suggested that most of the $\mathrm{Zn}$ was removed during the preparation of the material for TEM. In this case the observation of the dried fungus with SEM is more reliable. In addition. SEM observations also showed the presence of $\mathrm{Si}$ and $\mathrm{Al}$ in the cell wall, which would suggest the presence of aluminosilicate complexes on the wall surface. Up to $3.1 \%$ of Si were found in fungal walls of the mantle of Pisolithus mycorrhizas while the $\mathrm{Ca}$ content reached $2.5 \%$, in comparison to the Si content of diatoms ranging from 3.5 to $15 \%$ and $\mathrm{Ca}$ ranging from 10 to $35 \%$ dry weight depending on the species (unpublished data, obtained with the same EDS method). Generally mycorrhizas from industrial wastes contained higher amounts of $\mathrm{Si}$ than mycorrhizas from natural soils. Mycorrhizas of $P$. arrhizus differed from all the hitherto analyzed mycorrhizas in the content of $\mathrm{Si}$, which was higher than that of $\mathrm{Ca}$. The high $\mathrm{Si}$ and $\mathrm{Ca}$ content might be responsible for the biofiltering of $\mathrm{Al}$ in the cell wall of the mycelium of this species. The material which was excreted on the surface of the extramatrical mycelium and on the mycelium forming the fungal mantle of $P$. arrhizus mycorrhizas was also comparatively rich in such elements as sulphur and phosphorus.

There were no statistically significant differences between extramatrical hyphae and the hyphae forming the fungal mantle in respect to metal content. This is in contradiction with the data obtained by Denn y and W i l$\mathrm{k}$ in s (1987) for other species of ectomycorrhizal fungi forming mycorrhizas with Betula spp. where extramatrical mycelium was the main place of heavy metal sequestration.

In the case of $P$. arrhizus mycorrhizas from zinc wastes in Poland $\mathrm{Cu}, \mathrm{Cd}$, $\mathrm{Pb}, \mathrm{Ni}, \mathrm{Cr}$ were not found by the EDS method (probably below the detection 
level). When fruit-bodies and mycorrhizas are compared similar tendencies for accumulation of high levels of $\mathrm{Al}$ were observed. However, such elements as $\mathrm{Zn}$ and $\mathrm{Fe}$ reached higher values than in other mycorrhizas. The content of these two elements within fruit-bodies was on an average level as the levels given by T y le r (1980). More exact comparison of data obtained with two different techniques could be misleading as EDS technique involves calculations based on standardless analysis or on virtual standards which are not sufficient for biological material. Increased levels of $\mathrm{Fe}$ and $\mathrm{Zn}$ in mycorrhizas suggested differences in heavy metal sequestration between sporocarps and mycorrhizas.

When analysing the heavy metal content within ectomycorrhizas it is very important to bear in mind that not only species and strains of fungi differ in element sequestration properties but also the presence of plant influences the fungal activity, which results in structural and metabolic modifications leading to differences in abilities to immobilize elements even within the same mycorrhiza ( $\mathrm{T}$ u r n a u et al. 1996; L e y v a I et al. 1997). Generally much more substances which could take part in this phenomenon are localized within the outer fungal mantle.

The selection of species for recultivation of industrial wastes only on the basis of metal content within fruit-bodies has a limited value. The ability of extramatrical mycelium and hyphae forming mycorrhizal mantle to immobilize potentially toxic elements might indicate biofiltering properties though the next step should include investigations on the ability of the fungus to prevent element uptake by the plant. Further investigations should be carried out using, for example, the techniques designed by $\mathrm{J}$ e $\mathrm{n} \mathrm{t} \mathrm{s} \mathrm{ch} \mathrm{k} \mathrm{e} \mathrm{et} \mathrm{al.} \mathrm{(1991).}$

\section{Acknowledgements}

The scanning electron microscope was donated by the Foundation for Polish Science (SUBIN 94) to the Department of Electron Microscopy of Jagiellonian University. The authors are indebted to Prof. Dr. Wincenty Kilarski (Director of the Department of Electron Microscopy) for his help and comments during the work and to Mrs. J. Faber for her excellent help when working with EDS. The work was financially supported by the Polish Committee for Scientific Research (KBN) - project no. PB 0860/P04/96/11 and by European Commission - project ERBIC20CT970002.

\section{REFERENCES}

A g e r e r R. 1987-1995. Colour Atlas of Eetomycorrhizac. Einhorn-Verlag, Sehwäbisch Gmünd. $\mathrm{C} \mathrm{o} \mathrm{ch} \mathrm{tan} \mathrm{e}$ C. E. 1978. Aluminium and $\mathrm{pH}$ effects on growth and mycorrhizal relationships of Pisolithus finctorius. (Master's thesis) lowa State University.

De n n y H., R i g e I. 1995. Fungal slime and its role in the myeorrhizal amelioration of zine toxicity to higher piants. New Phytol. 130: 251-257.

De n n y H. J., Wilk in s D. A. 1987. Zinc tolerance in Bemla spp. IV. The mechanism of ectomycorrhizal amelioration of zinc toxicity. New Phytol. 106: 545-553. 
Derbseh H., S c h m it t J. A. 1987. Atlas der Pilze des Saarlandes 2: Nachweise, Okologie: Nat. Landsch. Sonderb. 3: 1-816.

G r u h n C. M., M ille r O. K. 1991. Eflect of copper on tyrosinase activity and polyamine content of some ectomycorrhizal fungi. Mycol. Res. 95 (3): 268 - 272.

Howe R., Evans R. L, Ketteridge S. W, 1997. Copper-binding proteins in ectomycorrhizal fungi. New Phytol. 135: 123-131.

Ientschke G, Godbold D. L, Hutterman n A. 1991. Culture of mycorrhizal tree seedlings under controlled conditions: effects of nitrogen and aluminium. Physiol. Plant: 81: $408-416$

Kag i J. H. R., K o j i m a $\mathrm{Y}, 1987$. Chemistry and biochemistry of metallothionein, In: J, H. R. $\mathrm{Kag}$, Y. K o.j i m a (eds.) Metallothioneins II. Birkhauser Veri., Basel: 25-61.

K r e is e 1 H 1987. Pilflora der Deutschen Demokratischen Republik. Fischer, Jena.

Landis T. D., Tinus R. W. MeDonald S. E., Barnett J. P. 1990. The container tree Nursery manual. 5, USDA Forest Service, Public Affairs Off., Washington. $\mathrm{DC}$.

Lisiewska M. Siedlaczek S 1982. The initial investigations on the occurrence of macromycetes on the coal mine heap "Smolnica". Arch Ochr. $\$$ rod. 1-4:93-110.

Leyva I C., Tura a K K., Has e I wand ter K. 1997. Effect of heavy metal pollution on mycorrhizal colonization and function: physiological, ecological and applied aspects. Mycorrhiza 7: 139-153.

M ed v c R. J., S a y r e W. G. 1994. Heavy metals in rod pines, basidiomycete sporocarps and soils on bituminous stripmine spoils, J. Pensylv. Acad, Sc. 68 (3): 131-135

Morselt A. F. W. $\mathrm{S} m$ its W. T. M., L i m o n a rd T. 1986. Histochemical demonstration of heavy metal tolerance in ectomyconhizal fungi. Plant Soil 96:417-420

Sehier G. A., M c Q u a t t i c C. J. 1995. Elfect of aluminum on the growth, anatomy, and nutrien content of ectomycorrhizal and nonmycorrhizal eastern white pine seedlings. Can. J. For. Res. 25: 1252-1262.

$\mathrm{Sch}$ r a m m J. R. 1966. Plant colonization studies on block wastes from anthracite mining in Pennsylvania. Trans. Am. Philos, Soc. 56: $1-190$.

T a m P. C. F. 1995. Heavy metal tolerance by ectomycorrhizal fungi and metal amelioration by Pisolinhus tinctorius. Mycorrhiza 5 (3): 191-187.

Tokarska-Guzik B, Rostans ki A., K I otz S, 1991, Roslinnosc haldy pocynkowej w Katowicach-Wełnowcu. Acta Biol. Siles. 19 (36): 94-102.

Turnau K, Dexheimer J. 1995. Acid phoshatase activity in Pisolithus arrhizies mycelium treated with cadmium dust. Mycorrhiza 5 (3): 205-211.

Turnau K. Kottke I. Dexheimer J. Bot ton B. 1994. Element distribution in Pisolithus arrhizus mycelium treated with cadmium dust. Bot. Ann. 74: 137-142,

Turnau K., Kottke I. Dexheimer J, 1996. Toxic element filtering in Rhizopogon reseolus/Pinus sylvestris mycorrhizas collected from calamine dumps. Mycol. Res. $100 ; 16-22$

Tyle r G. 1980. Metals in sporophores of Basidianyeetes. Trans. Br, Mycol. Soc. 74 (1): $41-49$.

We iss M. 1991. Pisolithus finctorius. In: R. A g e r e r (ed.) Colour Atlas of Ectomycorrhizae, plate 63. Einhorn-Verl. Schwäbisch Gmünd

W e is s M. 1992. Ectomycorrhizac formed by Pisolirinus tincioritus (Besidionycetes) on Norway spruce, Crypt. Bot. 2: $337-344$. 


\section{Zawartość metali w owocnikach i mikoryzach Pisolithus arrhizus zebranych na hałdach cynkowych}

\section{Streszezenie}

Pisolithas arrhizus wybrany zostat do badań ze względu na jego szczegóna odpornośc na wysokie stęzenia metali cięzkich. Zawartošc metali w owocnikach $i$ mikoryzach oznaczono w celu stwierdzenia przydatnosci ich jako wskaźnikow zanieczyszczenia oraz dla sprawdzenia czy mikoryzy mają zdolnosé akumulowania metali cięzkich w mufee. Owocniki i mikoryzy zebrane zostały na haldach cynkowych w Katowicach - Welnoweu i przeanalizowane za pomoca spektrofotometru AAS oraz mikroskopu skaningowego z przystawka EDS. W analizowanym materiale stwierdzono istotne różnice w zawartości metali. Owocniki akumulowaly glin (do $640 \mathrm{\mu g} \mathrm{g}^{-1}$ ), poderas gdy w mufee obok glinu stwierdzono takł̉e dửe ilości cynku i jelaza, ktỏrym towanyszyly wapt i krzem. Zawartosc metali rosta w mufkach mikoryz starych lub martwych. Zdolnosć grzybni ekstramatrykalnej oraz grzybni budującej mufkẹ do wiąznia metali potencjalnie toksycznych wskazuje na przydatność mikoryzy w detoksyfikacji tych metali, ale ostateczna decyzja odnośnie np. wprowadzenia danego szczepu czy gatunku w ramach rekultywacji, powinna zostać podjẹta po zbadaniu efektywności w utrzymaniu tych clementów w formie niedostẹpnej dla rosliny. 